Images

vol.VIII/no.15-16

\section{Produkcja: łódzka Szkoła Filmowa}

Zacznijmy od elementarnego pytania: czy studencka etiuda filmowa jest utworem przynależącym w pełnoprawny sposób do sfery profesjonalnej produkcji filmowej?

Pytanie całkiem proste, jednak odpowiedź na nie okaże się nie tylko dużo trudniejsza, lecz, jak się zaraz przekonamy, znacznie bardziej złożona. Zabrzmi to jak niezamierzony paradoks - ale i tak, i nie.

Zjednej strony bowiem, twórcą czy też współtwórcą takiej etiudy jest ktoś, kto dopiero zdobywa zawodowe wtajemniczenie, studiując reżyserię, sztukę operatorską, scenariopisarstwo, grę aktorską itp., a zatem nie przysługuje mu jeszcze społeczny status pełnoprawnego profesjonalisty przynależny komuś, kto studia filmowe ukończył. $\mathrm{Z}$ drugiej strony jednak, wysokie wymogi warsztatowe stawiane twórcom takiej etiudy są wymogami w pełni profesjonalnymi. Należy więc oczekiwać, że ich spełnienie zaowocuje - i tak się przecież w bardzo wielu przypadkach działo i nadal dzieje - powstaniem filmu, który w niczym nie ustępuje produkcjom profesjonalnym. Co więcej, utwór taki ma nad nimi pewną przewagę. Bywa bowiem wolny od skazy ich rutyniarstwa, sztampy i braku indywidualnego wyrazu. W tym sensie niejednokrotnie góruje nad nimi pod względem artystycznym: zaskakującą świeżością, oryginalnością i odmiennością spojrzenia.

Wspomniany atut w przypadku interesujących nas produkcji nie tylko częstokroć występuje, ale też przesądza po latach o tym, że okazują się one na swój sposób atrakcyjne także dla współczesnego widza. Aby się o tym przekonać, potrzebne są mądre i przenikliwe analizy tych prac. Dokonują ich pedagodzy w ramach Szkoły, czasami również $\mathrm{w}$ przypadku konkursów i okazjonalnie organizowanych przeglądów zewnętrzni jurorzy i recenzenci. By jednak dostrzec i ocenić ich społeczną wartość, niezbędne są publiczne prezentacje tych filmów adresowane do szerokiej widowni. Dawniej były to konkursy etiud, dzisiaj, oprócz różnego rodzaju lokalnych konkursów, w Warszawie odbywa się doroczny festiwal etiud łódzkiej Szkoły Filmowej. Ciesząca się wielkim zainteresowaniem cykliczna impreza nosi nazwę „Łodzią po Wiśle”. Pokazy odbywają się w warszawskim kinie „Kultura” przy ulicy Krakowskie Przedmieście, a organizatorem festiwalu jest PWSFTviT (w roku 2011 odbyła się już dziewiąta edycja przeglądu).

Etiudy zrealizowane w łódzkiej Szkole Filmowej na przestrzeni kilkudziesięciu lat kręcili najwięksi: Munk, Wajda, Wójcik, Polański, Skolimowski, Rybczyński, Brzozowski, Karabasz, Matyjaszkiewicz, Szczechura, Żebrowski, Zanussi, Barański, Marczewski, Kieślowski,
Poznań 2011

ISSN 1731-450x 
Koterski, Idziak, Stok, Petrycki, obaj Łozińscy, Janusz Majewski, Lech Majewski i wielu innych.

Etiuda niesie z sobą ryzyko popełnienia błędu. Błąd i z góry założone naturalne prawo do niego jest dobrym prawem każdego studenta. To, że film może się nie udać i zakończyć niepowodzeniem, stanowi sens każdego ćwiczenia zarówno przyszłego reżysera, jak i operatora. Małe formy przyszłych wielkich mistrzów kina mogą uzyskać ostatecznie bardzo różny kształt: zarówno udatny, jak i dalece niedoskonały, czy wręcz nieudany. W każdym z indywidualnych przypadków są one efektem próby warsztatu - filmowym zadaniem, z jakim się zmierzyli. Etiuda filmowa jest w końcu niczym innym jak całkiem dosłownie właśnie warsztatową 'próbą' - reżysersko-operatorskim ćwiczeniem ręki, oka i ucha, które pozwala praktycznie przetestować własne umiejętności i pomaga osiągnąć adeptowi wyższy stopień wtajemniczenia.

Wprowadzając Czytelnika w ten ciekawy i ważny (nie tylko środowiskowo) temat, który będzie cyklicznie rozwijany w kolejnych numerach „Images”, chciałbym najpierw wydobyć i podkreślić ważny kulturowy artefakt w postaci istnienia Archiwum Filmowego Państwowej Wyższej Szkoły Filmowej, Telewizyjnej i Teatralnej im. Leona Schillera. W łódzkim Archiwum spoczywają gromadzone od początku istnienia Uczelni kopie wielkiej liczby etiud szkolnych nakręconych przez studentów Wydziału Reżyserii oraz Wydziału Operatorskiego. Jest to zbiór bardzo pokaźny. Wizyta w łódzkiej filmotece uzmysławia badaczowi istnienie tysięcy filmów fabularnych i dokumentalnych zrealizowanych od roku 1949 do chwili obecnej. Warto w tym miejscu dodać, iż lwią część tego unikatowego archiwum stanowią prace nakręcone na najszlachetniejszym $\mathrm{z}$ istniejących nośników sztuki ruchomego obrazu, światłoczułej taśmie $35 \mathrm{~mm}$.

Realizacja filmu na taśmie $35 \mathrm{~mm}$ była zawsze i nadal jest przedsięwzięciem bardzo kosztownym. Wydawać by się mogło, iż etiuda studencka $\mathrm{z}$ natury rzeczy nie wymaga od władz Uczelni konieczności ponoszenia aż takich kosztów. A jednak, od samego początku istnienia Państwowej Wyższej Szkoły Filmowej - pomimo chronicznego braku nie tylko niezbędnych środków finansowych, ale nawet samej negatywowej taśmy $35 \mathrm{~mm}$ i odpowiedniego sprzętu filmowego - przyjęto jako zasadę, że młodzi reżyserzy i operatorzy będą realizować swoje ćwiczenia warsztatowe na takim właśnie nośniku.

Powstaje pytanie, jak wielki procent etiud realizowany jest dzisiaj na taśmie filmowej $35 \mathrm{~mm}$ ? I pytanie następne, czy współczesne, coraz doskonalsze cyfrowe techniki realizacji utworu filmowego (czytaj: kinematograficznego) nie wyparły już doszczętnie tamtej klasycznej technologii? Stoi za nimi uzasadniona obawa o przyszły los najbardziej szlachetnej z istniejących technik, czyli zdjęcia na taśmie 35 mm. - Aby uzyskać kompetentną i w pełni miarodajną odpowiedź w tej pierwszorzędnie istotnej kwestii, zwróciłem się z prośbą o konkretne dane do pełnomocnika rektora PWSFTViT do spraw produk- 
cji, pana Marcina Malatyńskiego. Precyzyjne dane i zestawienia liczbowe, jakie od niego otrzymałem, w pełni potwierdzają przypuszczenie, że jednak nie. W odróżnieniu od wielu innych szkół filmowych na świecie, taśma $35 \mathrm{~mm}$ - mimo ekspansji nowych systemów zapisu pozostaje nadal podstawowym nośnikiem etiud kręconych w łódzkiej Uczelni.

Proporcje między jednym a drugim nośnikiem przedstawiają się następująco: rok 2006 - 97 tytułów na taśmie $35 \mathrm{~mm}$ i 72 na nośniku magnetycznym bądź cyfrowym. Rok 2007 - odpowiednio: 87 i 72. Rok 2008 - 101 i 67. Rok 2009 - 82 i 77. Rok 2010 - 88 i 87.

$\mathrm{O}$ istnieniu pewnej stałej tendencji można również mówić w przypadku etiud fabularnych i etiud dokumentalnych. Co zrozumiałe, taśma $35 \mathrm{~mm}$ była wykorzystywana zdecydowanie częściej przy realizacji etiud fabularnych niż dokumentalnych. Dla przykładu: w roku 2008 proporcja ta wynosiła 38:21, w 2009 47:27, a w roku 2010 - nawet 52:18. Wymowne są również dane dotyczące etiud realizowanych na Wydziale Operatorskim. Tu także utrzymuje się bardzo wysoka liczba filmów kręconych na taśmie $35 \mathrm{~mm}$. W roku 2006 było ich w sumie 74 . W roku 2007 - 85. W 2008 - ponownie 74. W roku 2009 - 73. I w roku 2010 - znów 84.

Przy okazji analizy powyższych danych warto jeszcze zwrócić uwagę na łączną liczbę etiud, jakie powstają rokrocznie w Łodzi. W roku 2006 - 164 tytuły. W roku 2007 - 159. W roku 2008 - 168. W 2009 - 159. Jak widać, mamy do czynienia z bardzo wysoką średnią, dobrze świadczącą zarówno o pedagogicznych ambicjach, jak i potencjale produkcyjnym Szkoły. Nie koniec na tym, bowiem w roku 2010 nakręcona została imponująco duża, rekordowa w historii Szkoły liczba aż 175 tytułów! W ostatnich pięciu latach przybywało więc w kolekcji etiud szkolnych PWSFTViT średnio około 160 tytułów rocznie!

Jest rzeczą bardzo ciekawą, że ów zbiór złożony z tysięcy filmów nakręconych dotąd przez studentów łódzkiej Szkoły Filmowej ma charakter wielotorowy. Składa się nań wiele różnych nurtów poszukiwań. Znajdują się w tym zbiorze utwory ewidentnie autorskie w rozumieniu zarezerwowanym dla kina autorskiego. Oprócz nich są również liczne eksperymenty warsztatowe, z których niemała część stanowi klasyczną dzisiaj, unikatową kolekcję wczesnych prac i poszukiwań polskiej awangardy filmowej lat siedemdziesiątych - grupy znanej w Polsce i na świecie pod nazwą Warsztatu Formy Filmowej (Józef Robakowski, Paweł Kwiek, Tadeusz Junak, Andrzej Barański, Ryszard Waśko, Wojciech Bruszewski, Zbigniew Rybczyński, Małgorzata Potocka i inni).

Wcześniej kolekcja etiud studentów łódzkiej Szkoły Filmowej bywała już co prawda przedmiotem zainteresowania badaczy polskiego kina, jednak tylko w wybranych aspektach i pod ściśle określonym kątem. W połowie lat siedemdziesiątych Tadeusz (Karol) Lubelski opublikował artykuł o poszukiwaniach filmowych Warsztatu Formy 
Filmowej[1]. Natomiast kilka lat temu ukazała się drukiem dysertacja doktorska Joanny Preizner, która w pracy swej zajęła się wizerunkami PRL w etiudach nakręconych przez studentów łódzkiej Szkoły Filmowej w latach 1949-1960[2].

Powróćmy w tym miejscu do zadanego na początku pytania. Tym razem nie będziemy już jednak pytać tylko o status etiudy studenckiej względem profesjonalnej produkcji filmowej, lecz o coś znacznie ważniejszego, a mianowicie o jej miejsce i znaczenie w kulturze filmowej. To kwestia kluczowa dla kulturotwórczej roli i funkcji, jaką tego rodzaju twórczość pełniła i nadal pełni w naszym życiu filmowym. Produkcja etiud szkolnych, mimo stawianych jej wysokich wymogów warsztatowych, nie należy do sfery twórczości profesjonalnej. Stanowi ona w gruncie rzeczy osobne pole kultury i twórczości filmowej. Paradoks, na który zwróciliśmy już wcześniej uwagę, polega na tym, że realizowali je i nadal realizują adepci w zawodzie reżysera i operatora filmowego - ludzie, dla których celem jest akces do grona profesjonalnych filmowców.

Etiuda jest ex definitione próbą, lecz próbą szczególnego rodzaju. Liczy się w niej poszukiwanie. A jeśli tak, to godną podkreślenia wartością etiudy jest odwaga artystyczna jej twórców. Nie chodzi przy tym o wybujały indywidualizm przyszłego artysty usiłującego uprawiać swą sztukę solo i w pojedynkę. W szczególnej cenie jest co innego, a mianowicie zespołowy charakter twórczości, wymiana inspiracji, synergia twórczych działań. Wewnętrzny obieg etiud studenckich, jak długo istnieje łódzka Szkoła Filmowa, zawsze polegał na wywoływaniu fermentu i ewokowaniu refleksji środowiskowej. Refleksji szczególnego rodzaju: zdolnej prowokować zmiany i inspirującej kierunek twórczego rozwoju zarówno autora, jak i pośrednio innych. Etiudy Romana Polańskiego, dla przykładu, wywarły ogromny wpływ na formułę etiudy studenckiej uprawianą w Łodzi. Wpływ ten, mimo upływu tylu ponad półwiecza w niektórych przypadkach okazuje się widoczny praktycznie do dzisiaj. Dobra etiuda jest zawsze wychylona w przyszłość, zapowiada ona coś, co dopiero nadejdzie. Staje się wówczas laboratoryjną próbką nadchodzących przemian.

Liczone w dziesiątki lat łódzkie dzieje tej domeny twórczości filmowej stanowią ważną cząstkę nienapisanej historii polskiego kina. Etiudy w zaproponowanym tutaj ujęciu należą ewidentnie do alternatywnej historii naszej kinematografii. Wiele $\mathrm{z}$ nich, ze słynną etiudą Romana Polańskiego Dwaj ludzie z szafą na czele, obrosło legendą i ma dzisiaj - nie tylko w kraju, ale i na świecie - status utworów kultowych. Wiele dokonań, niegdyś eksperymentalnych, przyniosło po latach kontynuacje, co ciekawe, także w kinie głównego nurtu.

[1] K. Lubelski, Warsztat Formy Filmowej - próba dzisiejszej awangardy, w: $Z$ dziejów awangardy filmowej, red. A. Helman, K. Lubelski, W. Banaszkiewicz, Katowice 1976.
[2] J. Preizner, $P R L$ w obiektywie studentów łódzkiej filmówki 1949-1960, Kraków 2007. 
Etiuda jako forma i gatunek wypowiedzi przeszła długą ewolucję. Jej współcześnie realizowane wersje z jednej strony nawiązują do tradycji, z drugiej - z premedytacją odchodzą od niej w poszukiwaniu nowych form wypowiedzi.

Jedno wszelako nie uległo zmianie. Znaczenie tego rodzaju twórczości dla rozwoju rodzimej kultury filmowej. Opisując owo znaczenie, warto zwrócić uwagę na trzy jego zasadnicze aspekty:

- aspekt produkcyjny (edukacja nowych kadr i permanentne odtwarzanie zawodu filmowca poprzez doskonalenie warsztatu);

- aspekt artystyczny (laboratorium nowej sztuki, poszukiwanie oryginalnych form wyrazu, a także konkurencyjny charakter autorskiej rywalizacji na drodze do osiągnięcia mistrzostwa); oraz

- aspekt prognostyczny (dynamika sztuki i twórczości filmowej polegająca na dążeniu do zmiany; etiudy wielokrotnie stawały się zapowiedzią zjawisk, które dopiero torują sobie drogę do świadomości społecznej).

Jak z tego wynika, zarówno pojedyncze utwory, jak i produkcja etiud filmowych stanowi wprawdzie margines (w odniesieniu do rutyniarskiej codzienności życia filmowego i względem filmów mainstreamowych), ale rola społeczna, jak jej przypada, do marginalnych z pewnością nie należy. I z tego właśnie powodu warto odkrywać i studiować intrygujące pole twórczego działania przyszłych mistrzów kina, jakie ona stanowi.

Niedawna cykliczna prezentacja dawnych i nowszych etiud studenckich łódzkiej Szkoły Filmowej emitowana w latach 2009-2011 na antenie TVP Kultura pod tytułem Skarby Filmoteki, w której znalazły się zarówno najstarsze filmy pochodzące jeszcze $\mathrm{z}$ okresu stalinowskiego, jak i etiudy bliskie współczesności, skłania do wniosku, że właściwe odkrycie niezwykle cennych zbiorów spoczywających w tym mało znanym archiwum jest ciągle przed nami.

Za pomoc w pracy nad niniejszym artykułem pragnę szczególnie podziękować: Katarzynie Mące-Malatyńskiej oraz Marcinowi Malatyńskiemu. 


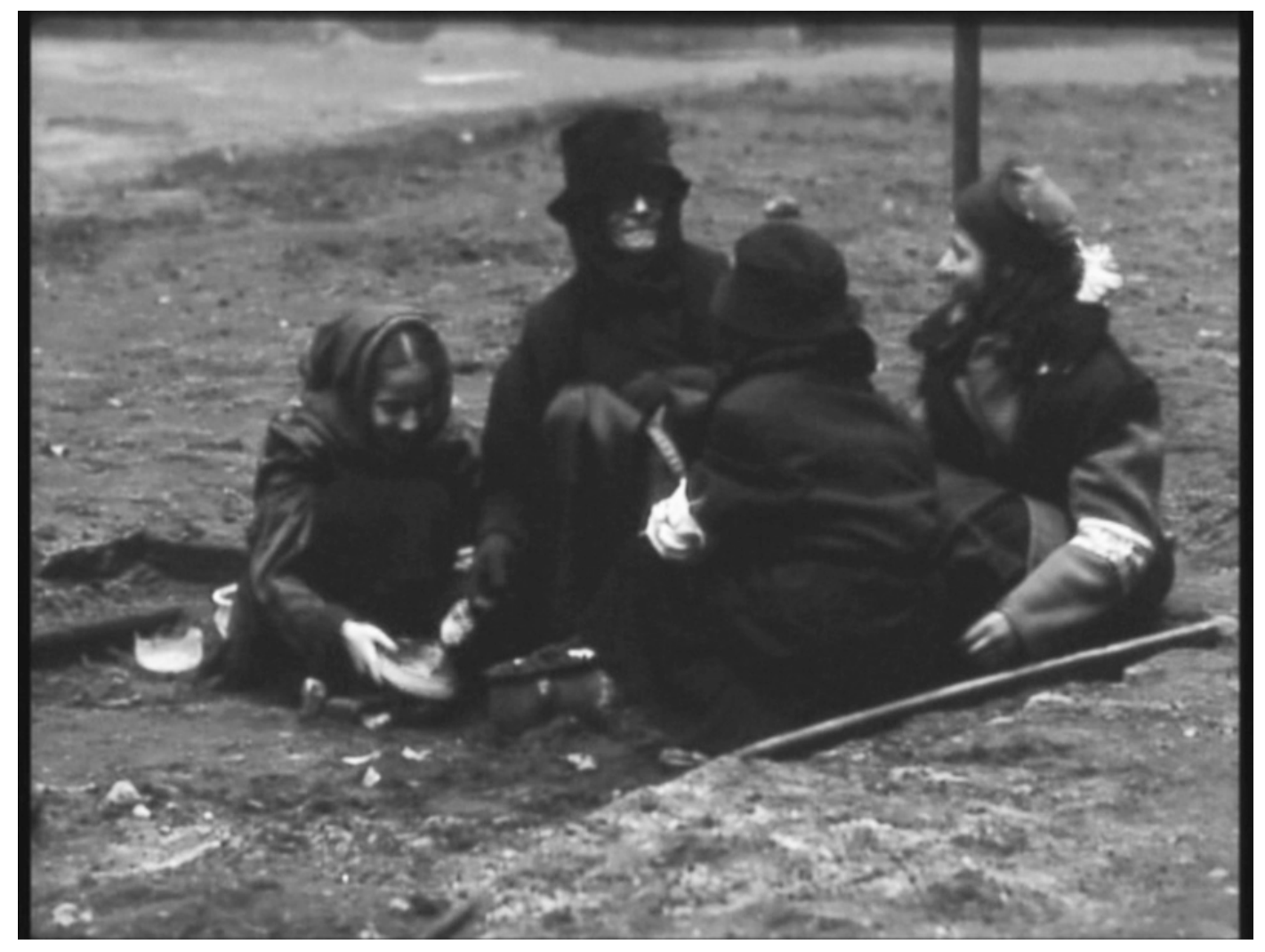

Głód 